\title{
Model Struktural Faktor - Faktor yang Berpengaruh terhadap Profitabilitas dengan Net Interest Margin sebagai Variabel Intervening (Studi pada Bank Go Public di Indonesia Pada Tahun 2014 - 2018)
}

\author{
Astohar ${ }^{1)}$ \\ astohar@stietotalwin.ac.id \\ Mirna Dyah Praptitorini ${ }^{2)}$ \\ dyah@stietotalwin.ac.id \\ Sekolah Tinggi Ilmu Ekonomi Totalwin Semarang
}

\begin{abstract}
Banking is a financial institution that has a role in the financial system in Indonesia. Banking financial performance or banking health can be seen through profitability performance. In measuring the profitability of banks that go public, this study uses Return On Assets (ROA). ROA is more focused on the ability of banks to get earnings in company operations. This research is a development of Hardiyanti (2016) research by adding Capital Adequacy Ratio (CAR) variable.

This study takes the object of go public banking in Indonesia as many as 43 banks. The sample used for research is 41 banks (2 banks cannot be used). The sampling method uses purposive sampling. The analysis tool uses multiple regression with three stages of regression.

The results showed that the Loan to Deposit Ratio (LDR) had a significant positive effect on Net Interest Margin (NIM) and no significant negative effect on Return On Assets (H1 and H4 was rejected). Operating Costs to Operating Income (BOPO) have a significant negative effect on Net Interest Margin (NIM) and on Return On Assets (H2 and H5 received). Capital Adequacy Ratio (CAR) is proven to have an insignificant positive effect on Net Interest Margin (H3 rejected) and a significant negative effect on Return On Assets (H6 received). Net Interest Margin (NIM) of Go Public Banks in Indonesia has a significant positive effect on Return On Assets (H7 received). The sobel test results show that Net Interest Margin (NIM) is proven as a mediating variable for Loan To Deposit Ratio (LDR) and BOPO on Return On Assets (ROA), whereas the Capital Adequacy Ratio (CAR) variable is not proven as mediation.
\end{abstract}

Keywords: Loan to Deposit Ratio (LDR), Operaional Costs and Operating Income (BOPO), Capital Adequacy Ratio (CAR), Net Interest Margin (NIM) and Return On Assets (ROA)

\begin{abstract}
ABSTRAK
Perbankan merupakan lembaga keuangan yang memiliki peranan dalam sistem keuangan di Indonesia. Kinerja keuangan perbankan atau kesehatan perbankan dapat dilihat melalui kinerja profitabilitas. Dalam mengukur profitabilitas bank yang go public, penelitian ini menggunakan Return On Asset (ROA). ROA lebih memfokuskan pada kemampuan perbankan untuk memperoleh earning dalam operasi perusahaan. Penelitian ini merupakan pengembangan dari penelitian Hardiyanti (2016) dengan menambah variabel Capital Adequacy Ratio(CAR).

Penelitian ini mengambil obyek pada perbankan go public di Indonesia sebanyak 43 perbankan. Sampel yang digunakan untuk penelitian adalah sebanyak 41 bank (2 bank tidak dapat digunakan). Metode pengambilan sampel menggunakan
\end{abstract}


purposive sampling. Alatanalisis menggunakan regresi berganda dengan tiga tahapan regresi.

Hasil penelitian menunjukkan bahwa Loan to Deposit Ratio (LDR) mempunyai pengaruh positif signifikan terhadap Net Interest Margin (NIM) dan negative tidak signifikan terhadap Return On Asset (H1 dan H4 ditolak). Biaya Operasional terhadap Pendapatan Operasional (BOPO) mempunyai pengaruh negative signifikan terhadap Net Interest Margin (NIM) dan terhadap Return On Asset (H2 dan H5 diterima). Capital Adequacy Ratio (CAR) terbukti mempunyai pengaruh positif tidak signifikan terhadap Net Interest Margin (H3 ditolak) dan negative signifikan terhadap Return On Asset (H6 diterima). Net Interest Margni (NIM) Bank Go Public di Indonesia mempunyai pengaruh positif signifikan terhadap Return On Asset (H7 diterima). Hasil perhitungan sobel test menunjukkan bahwa Net Interest Margin (NIM) terbukti sebagai variable mediasi untuk Loan To Deposit Ratio (LDR) dan BOPO terhadap Return On Asset (ROA), sedangkan pada variabel Capital Adequacy Ratio (CAR) tidak terbukti sebagai mediasi.

Kata Kunci : Loan To Deposit Ratio (LDR), BiayaOperaional Dan PendapatanOperasional (BOPO), Capital Adequacy Ratio (CAR), Net Interest Margin (NIM) Dan Return On Assets (ROA)

\section{PENDAHULUAN}

Perbankan memiliki peranan yang sangat penting dalam sistem keuangan di Indonesia, dimana dalam kehidupan masyarakat sebagian besar melibatkan jasa dari sektor perbankan (Putrianingsih dan Yulianto, 2016). Perbankan sebagai lembaga keuangan lebih mengedepankan kepercayaan dan jasa, sehingga bank berupaya menarik nasabah baru serta mempertahankan nasabah lamanya. Hal ini dilakukan untuk meningkatkan dananya untuk menunjang peningkatan pemberian kredit dan jasanya. Untuk menunjang keberlangsungan dan kontinuitas perbankan tersebut harus sehat, karena kondisi yang tidak sehat akan mengakibatkan lambannya kegiatan investasi serta pertumbuhan perekonomian (Defri, 2012).

Perbankan pada saat ini terjadi persaingan yang kompetitif sebagai akibat dari banyaknya bank yang beroperasi dengan berbagai variasi produk jasa perbankan. Menurut Rahmani (2017) Bank mulai meningkatkan keunggulan kompotetitifnya untuk memberikan layanan yang terbaik kepada para nasabahnya melalui berbagai macam produk perbankan seperti produk dana, produk pinjaman atau produk jasa lainnya. Berbagai inovasi yang diberikan perbankan berakibat adanya risiko dalam pengelolaan uang masyarakat yang dikelola oleh perbankan tersebut (Ghozali, 2007). Dalam persaingan yang tinggi dan beratnya tantangan yang dihadapi, bank pada umumnya mampu mempertahankan kinerja positif.

Kinerja keuangan perbankan atau kesehatan perbankan dapat dilihat melalui kinerja profitabilitas. Faktor-faktor yang mempengaruhi profitabilitas bank dapat bersumber dari berbagai kinerja profitabilitas yang ditunjukkan beberapa indikator. Menurut Bank Indonesia rasio profitabilitas yang penting bagi bank adalah return on asset (ROA) (Latifah dkk, 2012). Menurut Astohar (2016) return on asset (ROA) digunakan untuk mengukur profitabilitas bank. Hal ini juga sejalan dengan arahan dari Bank Indonesia sebagai pembina dan pengawas perbankan yang saat ini dibawah naungan Otorita Jasa Keuangan (OJK) lebih mengutamakan nilai profitabilitas bank. Return on asset (ROA) yang semakin besar dapat dikatakan semakin tinggi pula tingkat 
keuntungan yang dicapai bank, yang tentunya semakin optimal posisi bank tersebut dari sisi penggunaan aktiva (asset).

Profitabilitas untuk perbankan yang go public lebih tepat menggunakan return on asset (ROA), hal ini disebakan pada ROA lebih memfokuskan kemampuan perbankan untuk memperoleh earning dalam operasi perusahaan, sedangkan Return On Equity (ROE) hanya mengukur return yang diperoleh dari investasi pemilik perusahaan dalam bisnis tersebut (Marwadi, 2005, dalam Astohar, 2018). ROA merupakan rasio antara laba sebelum pajak terhadap total asset. semakin besar ROA menunjukan kinerja semakin baik, karena tingkat pengembalian (return) semakin besar.

Dalam penelitian ini return on asset digunakan sebagai ukuran kinerja dari perbankan. Semakin tinggi ROA merupakan indicator kinerja perbankan yang semakin baik, hal ini disebabkan tingkat pengembalian (return) semakin tinggi pula. Apabila ROA meningkat, berarti profitabilitas perusahaan meningkat, sehingga dampak akhirnya adalah peningkatan profitabilitas yang dinikmati oleh pemegang saham. Bank yang baik dan sehat ditandai adanya peningkatan profitabilitas, karena tingginya profitabilitas bank akan mampu membagikan deviden dengan baik (Husnan, 2012).

Banyak fakor yang mempengaruhi profitabilitas perbankan seperti loan to deposit ratio (LDR), biaya operasional dan pendapatan operasional (BOPO) secara langsung atau net interest margin (NIM) yang sebagai variable intervening (Hardiyanti, dkk, 2016). Likuiditas perbankan atau tingkat penggunaan dana pihak ketiga dibandingkan dengan dana yang disalurkan mempunyai pengaruh yang negative, dimana tingginya dana pihak ketiga yang justru akan menurunkan profitabilitas perbankan.

Hasil penelitian dari Ali dan Laksono (2017) menunjukkan bahwa tingkat likuiditas yang diproksi LDR yang meningkat justru akan menurunkan laba. Hasil penelitian ini didukung oleh Sudarmawanti dan Pramono (2017) ; Aprillya (2017) dan Astohar (2018) yang mana dana pihak ketiga yang banyak menganggur akan mengurangi profitabilitas perbankan. Hasil penelitian ini didukung oleh penelitian dari Simanjuntak (2016) dan Rahmani (2017) dimana meningkatnya LDR berdampak pada peningkatan profitabilitas perbankan.

Biaya operasional terhadap pendapatan operasional (BOPO) mempunyai pengaruh yang negative terhadap profitabilitas. Hasil penelitian Fajari dan Sunarto (2017) yang didukung oleh Sitepu (2016) ; Peling dan Sedana (2018) yang menunjukkan bahwa peningkatan BOPO berdampak pada penurunan Return on Asset (ROA). Hasil yang berbeda ditunjukkan oleh Alifah (2014) dimana dijelaskan bahwa penurunan dan peningkatan BOPO tidak berpengaruh terhadap ROA, demikian juga menurut Sintiya (2018) yang mana peningkatan dan penurunan BOPO tidak mempunyai dampak terhadap ROA.

Hasil penelitian dari Chandra (2013) rasio kecukupan modal mempunyai pengaruh yang negative terhadap profitabilitas perbankan (ROA). Hasil ini diperkuat oleh Astohar (2018) bahwa pencadangan rasio kecukupan modal yang tinggi justru berdampak pada menurunnya profitabilitas bank. Hasil ini berbeda dengan penelitian oleh Bernardin (2016) peningkatan rasio capital adequacy ratio berdampak pada peningkatan return on asset. Hasil berbeda dengan penelitian dari Fajari dan Sunarto (2017) bahwa peningkatan dan penurunan rasio CAR tidak berdampak pada return on asset (ROA).

Permasalahan dalam penelitian ini adalah menyempurnakan penelitian dari Hardiyanti (2016) dengan menambah variable capital adequacy ratio (CAR) juga mempunyai dampak yang negative dan signifikan terhadap profitabilitas bank (Bernadin, 2016). Variable capital adequacy ratio (CAR) dipilih karena variable ini masih terjadi perdebatan dalam mempengaruhi profitabilitas. Menurut Astohar (2016) 
rasio kecukupan modal berpengaruh positif terhadap profitabilitas yang didukung oleh Khoirunisa (2016) adanya peningkatan capital adequacy ratio (CAR) berdapak pada peningkatan profitabilitas. Hasil yang berbeda dari Putriningsih dan Yulianto (2013) yang mana peningkatan capital adequacy ratio $(C A R)$ justru menurunkan profitabilitas perbankan.

\section{TELAAH PUSTAKA DAN PENGEMBANGAN MODEL} Anticipated Income Theory

Teori anticipated income theory menunjukkan bahwa bankir mulai melihat portofolio pinjaman mereka sebagai sumber likuiditas. Teori ini mendorong para bankir untuk memperlakukan pinjaman jangka panjang sebagai sumber potensial likuiditas. Bagaimana seorang bankir dapat mempertimbangkan pinjaman hipotek sebagai sumber likuiditas (Alshatti, 2015). Perbankan diharapkan lebih agresif dalam memberikan kredit jangka panjang dimana cicilan pokok pinjaman dan bunga (bagi hasil bank syariah) dapat diharapkan dan dijadwalkan pembayarannya sesuai dengan jangka waktu yang telah ditetapkan. Portofolio pinjaman bank menyediakan aliran dana terus menerus yang terus berlanjut ke bank likuiditas. Meskipun pinjaman dalam jangka panjang, likuiditas bank tetap terjaga (Astohar, 2018).

\section{Trade off Between Liquidity and Profitability Theory}

Teori trade off between liquidity and profitability mengungkapkan adanya pertentangan antara tingkat likuiditas dengan aspek profitabilitas karena pada umumnya harta lancar dipertahankan untuk jaminan likuiditas pada saat yang bersaman bank mengalami permasalahan pengelolaan dana disaat dana deposito harus dikembalikan. Pengelola perusahaan (perbankan) berupaya untuk mendapatkan pengembalian penuh atas harta lancar dengan laba yang lebih tinggi dibandingkan harta tidak lancar untuk memaksimalkan profitabilitas. (Greuning dan Bratanovic, 2011).

\section{Profitabilitas}

Profitabilitas atau disebut dengan rentabilitas adalah kemampuan suatu perusahaan untuk menghasilkan laba selama periode tertentu. Dimana rentabilitas perusahaan menunjukkan perbandingan antara laba dengan aktiva atau modal yang menghasilkan laba tersebut (Defri, 2012). Menurut Slamet (2001 dalam Defri, 2012) profitabilitas ialah keefektifan operasiserta derajat keuangan suatu perusahaan. Profitabilitas bank merupakan suatu kemampuan bank dalam menghasilkan laba dengan memanfaatkan aktiva yang dimiliki dakan dalam suatu periode (Astohar, 2016).

Profitabilitas (profitability) atau diproksi dengan return on asset (ROA) adalah kemampuan suatu bank dalam memperoleh laba. Return on asset (ROA) merupakan perbandingan antara laba setelah pajak dengan total asset dalam satu periode (Bank Indonesia). Menurut Luciana dan Winni (2005) semakin besar ROA, semakin besar pula keuntungan yang dicapai perbankan sehingga kemungkinan suatu bank dalam kondisi bermasalah semakin kecil. Laba sebelum pajak adalah laba bersih dari kegiatan operasional sebelum pajak. Sedangkan rata-rata total aset adalah volume usaha atau aktiva.

Profitabilitas dari bank tidak hanya penting bagi pemiliknya, tetapi juga bagi pihak pihak lain di dalam masyarakat. Bila bank berhasil mengumpulkan cadangan dengan memperbesar modal, akan meminjamkan yang lebih besar karena tingkat kepercayaan atau kredibilitas meningkat (Simorangkir, 2004). Return on Asset (ROA) adalah rasio perbandingan antara laba setelah pajak dengan total aktiva (total asset) yang digunakan untuk mengukur kemampuan perusahaan dalam menghasilkan laba atas aktiva (total asset) yang dipergunakan dalam periode tertentu (Fauziah, 2011).

Apabila ROA perusahaan terjadi peningkatan dari tahun ke tahun, maka bisa dikatakan perusahaan semakin efisien dalam mengelola bisnisnya. Semakin besar ROA 
suatu bank, semakin besar pula tingkat keuntungan yang dicapai bank dan semakin baik posisi bank tersebut dari segi penggunaan asset (Dendawijaya, 2009). Semakin besar ROA maka kondisi bank akan semakin baik. (ROA) atau hasil pengembalian atas aset merupakan rasio yang menunjukkan hasil atas penggunaan aset perusahaan dalam menciptakana laba bersih, dengan kata lain rasio ini digunakan untuk mengukur seberapa besar jumlah laba bersih yang akan dihasilkan dari setiap rupiah dana yang tertanam dalam total aset (Hery 2015).

\section{Net interest margin (NIM)}

Menurut Ali dan Laksono (2017) net interest margin (NIM) digunakan untuk mengukur kemampuan bank dalam menghasilkan pendapatan dari bunga dengan melihat kinerja bank dalam menyalurkan kredit, dimana semakin besar NIM yang dicapai suatu bank maka akan meningkatkan pendapatan bunga atas aktiva produktif yang dikelola oleh bank yang bersangkutan, sehingga laba bank (ROA) akan meningkat (Ali dan Laksono., 2017). Net interest margin (NIM) penting untuk mengevaluasi kemampuan bank dalam mengelola resiko terhadap suku bunga. Saat suku bunga berubah, pendapatan bunga dan biaya bunga bank akan berubah. Sebagai contoh saat suku bunga naik, baik pendapatan bunga maupun biaya bunga akan naik karena asset dan liability bank akan dihargai pada tinkat yang lebih tinggi (Ariyanti, 2017)

Menurut Ali dan Laksono (2017) net interest margin (NIM) digunakan untuk mengukur kemampuan bank dalam menghasilkan pendapatan dari bunga dengan melihat kinerja bank dalam menyalurkan kredit, dimana semakin besar NIM yang dicapai suatu bank maka akan meningkatkan pendapatan bunga atas aktiva produktif yang dikelola oleh bank yang bersangkutan, sehingga laba bank (ROA) akan meningkat. Net interest margin (NIM) merupakan rasio yang menunjukkan kemampuan manajemen bank dalam mengelola aktiva produktifnya untuk menghasilkan pendapatan bunga bersih (Sudarmawanti dan Pramono, 2017).

Pendapatan bunga bersih diperoleh dari pemberian kredit atau pinjaman, sementara bank memiliki kewajiban beban bunga kepada deposan (Ali dan Laksono, 2017). Semakin besar rasio ini maka meningkatkan pendapatan bunga atas aktiva produktif yang dikelola bank sehingga kemungkinan suatu bank dalam kondisi bermasalah semakin kecil (Sitepu, 2016). Semakin besar perubahan Net interest margin (NIM) suatu bank, maka semakin besar pula profitabilitas bank tersebut, yang berarti kinerja keuangan tersebut semakin meningkat (Astohar, 2018). Semakin besar rasio ini maka akan meningkatkan pendapatan bunga atas aktiva produktif yang dikelola bank, sehingga kemungkinan suatu bank dalam kondisi bermasalah semakin kecil dan kinerja perbankan tersebut akan semakin baik (Milion, 2017). Ali dan Laksono (2017) memperkuat argument peneliti sebelumnya yaitu semakin tinggi net interest margin (NIM) akan berdampak pada peningkatan profitabilitas perbankan yang diproksi dengan return on asset.

Berdasarkan argument tersebut dapat dirumuskan hipotesis kedua $\left(\mathrm{H}_{7}\right)$ sebagai berikut :

$\mathrm{H}_{7}$ : net interest margin (NIM) mempunyai pengaruh yang positif dan signifikan terhadap return on asset (ROA) Bank Go Public

\section{Loan To Deposit Ratio (LDR)}

Loan to Deposit Ratio (LDR) merupakan rasio perbandingan antara seluruh jumlah kredit yang diberikan bank dengan dana yang diterima oleh bank (Dendawijaya, 2009). LDR merupakan salah satu rasio yang menunjukkan efektivitas suatu bank dalam menyalurkan dana. Menurut Lesmana (2008) semakin rendah LDR menunjukkan kurangnya efektifitas bank dalam menyalurkan kredit sehingga hilangnya kesempatan 
bank untuk memperoleh laba, sehingga diharapkan peningkatan LDR mampu meningkatkan profitabilitas (Khoirunnisa, dkk, 2016).

Menurut Simorangkir (2004), Loan to Deposit Ratio dinyatakan sebagai "Loan to Deposit Ratio merupakan perbandingan antara kredit yang diberikan dengan dana pihak ketiga, termasuk pinjaman yang diterima, tidak termasuk pinjaman subordinasi. Menurut Kasmir (2012) Loan to Deposit Ratio (LDR) merupakan rasio untuk mengukur komposisi jumlah kredit yang diberikan dibandingkan dengan jumlah dana masyarakat dan modal sendiri yang digunakan. Penilaian likuiditas bertujuan untuk mengukur seberapa likuid suatu bank.

Loan to Deposit Ratio (LDR) adalah rasio yang menyatakan seberapa jauh bank telah menggunakan uang para penyimpan (deposito) untuk memberikan pinjaman kepada para nasabahnya. Dengan kata lain jumlah uang yang dipergunakan untuk memberikan pinjaman adalah uang yang berasal dari titipan para penyimpan. LDR dapat dijadikan sebagai tolak ukur kinerja perbankan sebagai lembaga intermediasi, yaitu lembaga yang menghubungkan antara pihak yang kelebihan dana dengan pihak yang membutuhkan dana (Pandia, 2012).

Komponen faktor likuiditas yang digunakan dalam penelitian ini yakni LDR (Loan to Deposit Ratio). LDR akan menunjukan tingkat kemampuan bank dalam menyalurkan dan pihak ketiga yang dihimpun oleh bank yang bersangkutan. LDR (Loan to Deposit Ratio) digunakan untuk menilai likuiditas suatu bank dengan cara membagi jumlah kredit yang diberikan oleh bank terhadap dana pihak ketiga. Kredit yang diberikan merupakan total kredit yang diberikan tidak termasuk kredit kepada bank lain sedangkan dana pihak ketiga adalah giro, tabungan, simpanan berjangka, sertifikat deposito (tidak termasuk antar bank) (Ali dan Laksono, 2017).

Loan to deposit ratio (LDR) adalah perbandingan antara kredit yang diberikan dengan dana pihak ketiga (giro, tabungan, deposito, dan kewajiban jangka pendek lainnya). LDR ini menjadi salah satu tolok ukur likuiditas bank yang berjangka waktu agak panjang. Semakin tinggi LDR menunjukkan semakin jelek kondisi likuiditas bank, karena penempatan pada kredit juga dibiayai dari dana pihak ketiga yang sewaktuwaktu ditarik (Simanjutak, 2016). Loan Deposit Ratio (LDR) yaitu menunjukkan kemampuan suatu bank di dalam menyediakan dana kepada debiturnya dengan modal yang dimiliki oleh bank maupun dana yang dapat dikumpulkan oleh masyarakat (Achmad, 2003).

Peningkatan loan to deposit ratio $(L D R)$ menunjukkan kurangnya efektifitas bank dalam menyalurkan kredit sehingga hilangnya kesempatan bank untuk memperoleh laba (Sudarmawati dan Pramono (2017). Hal ini menunjukkan bahwa loan to deposit ratio yang tinggi menunjukkan kredit yang diberikan kepada masyarkaat atau nasabah adalah lebih besar dari dana pihak ketiga yang diterima, hal ini berdampak pada kemungkinan peningkatan risiko dan dampaknya adalah justru akan menurunkan profitabilitas bank (Ali dan Laksono, 2017). Berdasarkan argument tersebut dapat dirumuskan hipotesis kedua $\left(\mathrm{H}_{1}\right)$ dan Keepat $\left(\mathrm{H}_{4}\right)$ sebagai berikut :

Berdasarkan argument tersebut dapat dirumuskan hipotesis kedua $\left(\mathrm{H}_{1}\right)$ dan Keepat $\left(\mathrm{H}_{4}\right)$ sebagai berikut :

$\mathrm{H}_{1}$ : loan to deposit ratio $(L D R)$ mempunyai pengaruh yang negative dan signifikan terhadap net interest margin (NIM)

$\mathrm{H}_{4}$ : loan to deposit ratio $(L D R)$ mempunyai pengaruh yang negative dan signifikan terhadap return on asset (ROA)

\section{Pengaruh Biaya Operasional dan Pendapatan Operasional (BOPO)}


Biaya operasional digunakan untuk mengukur tingkat efisien dan kemampuan bank dalam melakukan kegiatan operasionalnya. Biaya operasional merupakan biaya yang dikeluarkan oleh bank dalam rangka menjalankan aktivitas usaha pokoknya (seperti biaya bunga, biaya tenaga kerja, biaya pemasaran dan biaya operasi lainnya).pendapatan operasional merupakan pendapatan utama bank, yaitu pendapatan bunga yang diperoleh dari penempatan dana dalam bentuk kredit dan pendapatan operasi lainnya (Astohar, 2018).

Menurut Fahmi (2015) Capital Adequacy Ratio atau sering disebut dengan istilah rasio kecukupan modal bank, yaitu bagaimana sebuah perbankan mampu membiayai aktivas kegiatannya dengan kepemilikan modal yang dimilikinya. Perubahan struktur modal akan mempengaruhi nilai perusahaan (Gitosudarmo, dalam Musyarofatun, 2013). Menurut Slamet dalam Sudarmanta (2016) besaran CAR akan membuat bank mampu menghadapi peyusutan nilai harta bank yang timbul akibat dari adanya resiko yang terjadi (Aprillya dkk, 2017).

Biaya operasional merupakan biaya yang dikeluarkan oleh bank dalam rangka menjalankan aktivitas usaha pokoknya (seperti biaya bunga, biaya tenaga kerja, biaya pemasaran dan biaya operasi lainnya).pendapatan operasional merupakan pendapatan utama bank, yaitu pendapatan bunga yang diperoleh dari penempatan dana dalam bentuk kredit dan pendapatan operasi lainnya. Semakin kecil rasio ini berarti semakin efisien biaya operasional yang dikeluarkan bank yang bersangkutan sehingga kemungkinan suatu bank dalam kondisi bermasalah semakin kecil (Sudamawati dan Pramono, 2017).

Hasil penelitian dari Defri (2012) menunjukkan bahwa BOPO mempunyai pengaruh yang negative terhadap profitabilitas. Hal ini menunjukkan bahwa tingginya biaya operasional akan berdampak pada turunnya pendapatan, sehingga menurunkan stabilitas perbankan (Martindas dkk, 2013). Hal yang sama ditemukan oleh Khoirunisa (2016) serta Ali dan Laksono (2017) bahwa variabel efisiensi operasi yang diproksikan dengan BOPO berpengaruh negatif terhadap kinerja perbankan yang diproksikan dengan Return on Assets (ROA).

Berdasarkan argument tersebut dapat dirumuskan hipotesis kedua $\left(\mathrm{H}_{2}\right)$ dan Hipotesis kelima $\left(\mathrm{H}_{5}\right)$ sebagai berikut :

$\mathrm{H}_{2}$ : BOPO mempunyai pengaruh yang negative dan signifikan terhadap net interest margin (NIM)

$\mathrm{H}_{5}$ : BOPO mempunyai pengaruh yang negative dan signifikan terhadap return on asset (ROA)

\section{Capital Adequacy Ratio}

Menurut Simanjuntak (2016) Capital Adequacy Ratio (CAR) atau biasa juga disebut Rasio Kecukupan Modal, adalah perbandingan antara modal bersih yang dimiliki bank dengan total asetnya. Secara umum, pengertian CAR (Capital Adequacy Ratio). Sedangkan menurut Dendawijaya (2009) CAR adalah rasio yang memperlihatkan seberapa besar jumlah seluruh aktiva bank yang mengandung risiko (kredit, penyertaan, surat berharga, tagihan pada bank lain) ikut dibiayai dari dan modal sendiri bank disamping memperoleh dana-dana dari sumber di luar bank, seperti dana masyarakat, pinjaman, dan sebagainya (Bernardin, 2016). Kecukupan modal atau capital adequacy ratioi (CAR) yang dimiliki bank untuk menunjang aktiva yang mengandung atau menghasilkan resiko.

CAR menjadi rasio kecukupan modal yang berfungsi menampung risiko kerugian yang kemungkinan dihadapi oleh bank. Semakin tinggi CAR, maka semakin baik kemampuan bank tersebut untuk menanggung risiko dari setiap kredit / aktiva 
produktif yang berisiko tertimbang. Menurut Rahmani (2017) semakin tinggi resiko rasio CAR maka semakin baik kondisi suatu bank dan jika nila CAR tinggi berarti bank tersebut mampu membiayai kegiatan operasinya. Tingginya CAR mengindikasikan bahwa bank tersebut mampu membiayai kegiatan operasional dan memberikan kontribusi yang cukup besar bagi profitabilitas (Kuncoro et al. 2002)

Capital adequacy ratio merupakan rasio kinerja bank untuk mengukur kecukupan modal yang dimiliki bank untuk menunjang aktiva yang mengandung resiko. CAR menjadi rasio kecukupan modal yang berfungsi menampung risiko kerugian yang kemungkinan dihadapi oleh bank. Semakin tinggi CAR, maka semakin baik kemampuan bank tersebut untuk menanggung risiko dari setiap kredit / aktiva produktif yang berisiko tertimbang (Rahmani, 2017). Capital adequacy ratio (CAR) adalah rasio kinerja bank untuk mengukur kecukupan modal yang dimilki bank untuk menunjang aktiva yang mengandung atau mengahasilkan resiko, misalnya kredit yang diberikan (Dendawijaya, 2005).

Tingginya CAR mengindikasikan bahwa bank tersebut mampu membiayai kegiatan operasional dan memberikan kontribusi yang cukup besar bagi profitabilitas (Kuncoro et al. 2002). Hal berbeda ditunjukkan oleh Khoirunisa (2016) yang mana hasil penelitian menunjukan bahwa capital adequacy ratio $(C A R)$ tidak berdampak terhadap profitabilitas bank, yaitu kenaikan dari CAR tidak serta merta meningkatkan profitabilitas bank. Lebih lanjut hasil penelitian dari Candra (2013) menunjukkan bahwa peningkatan capital adequacy ratio $(C A R)$ justru menurunkan profitabilitas perbankan.

Berdasarkan argument peneliti diatas dapat ditarik hipotesis ketiga $\left(\mathrm{H}_{3}\right)$ dan hipotesis keenam $\left(\mathrm{H}_{6}\right)$ sebagai berikut :

$\mathrm{H}_{3}$ : capital adequacy ratio modal berpengaruh negative dan signifikan terhadap net interest margin (NIM)

$\mathrm{H}_{6}$ : capital adequacy ratio modal berpengaruh negative dan signifikan terhadap return on asset (ROA)

\section{Kerangka Pikir}

Kerangka pikir dalam penelitian ini adalah sebagai berikut :

\section{Gambar 1 Kerangka Pikir Penelitian}

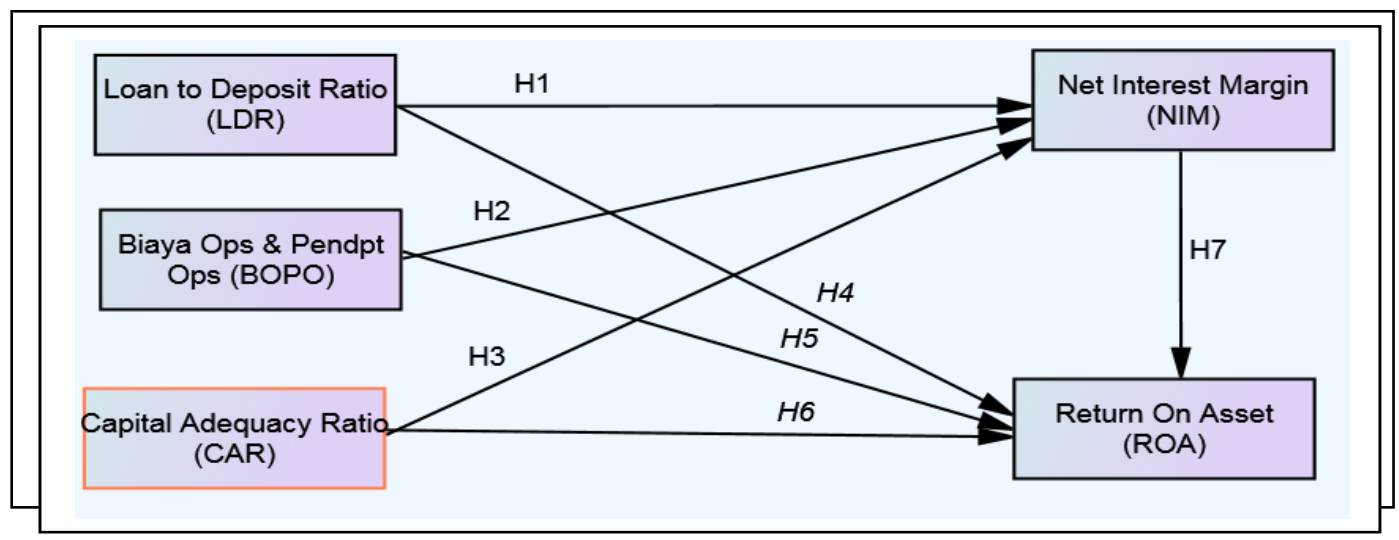

METODE PENELITIAN

\section{Definisi Konsep dan Operasional Variabel}

1. Loan to deposit ratio $(L D R)$

Menurut Dendawijaya (2005) loan to deposit ratio (LDR) menyatakan seberapa jauh kemampuan bank dalam membayar kembali penarikan dana yang dilakukan deposan dengan mengandalkan kredit yang diberikan sebagai sumber likuiditasnya. Berdasarkan SE Bank Indonesia no 12/11/DPNP/2010 : 


$$
\text { LDR }=\frac{\text { Pembiayaan }}{\text { Total Dana Pihak Ketiga + modal Inti }} \times 100 \%
$$

2. Beban Operasional terhadap Pendapatan Operasional (BOPO)

Rasio beban operasional terhadap pendapatan operasional atau lebih dikenal dengan istilah (BOPO) merupakan perbandingan dari beban operasional dengan diperbandingkan dengan pendapatan operasionalnya, dengan rumus sebagai berikut.

$$
\text { BOPO }=\frac{\text { Beban Operasional }}{\text { Pendapatan Operasional }} \times 100 \%
$$

3. Capital Adequacy Ratio (CAR)

Capital Adequacy Ratio (CAR) merupakan rasio dari kecukupan modal bank dalam mengukurnya dengan membandingkan antara jumlah modal bank dibandingkan dengan total aktiva tertimbang menurut risiko (ATMR), yang diukur sebagai berikut :

$$
\left.\mathrm{CAR}=\frac{\text { Modal }}{\text { ATMR }} \times 100 \%\right)
$$

\section{Net Interest Margin (NIM)}

NIM digunakan untuk mengukur kemampuan bank dalam menghasilkan pendapatan dari bunga dengan melihat kinerja bank dalam menyalurkan kredit, yang diukkur dengan rumus sebagai berikut : (Prima, dkk 2015)

$\mathrm{NIM}=\frac{\text { Pendapatan Bunga Bersih }}{\text { Aktiva Produktif }} \times 100 \%$

5. Return on asset (Profitabilitas Bank Go Public)

Return on asset (ROA) sebagai salah satu pengukur profitabilitas bank karena Bank Indonesia sebagai pemegang regulasi bank lebih mengutamakan nilai profitabilitas suatu bank, yang diukur sebagai berikut (Sartono, 2010):

$$
\mathrm{ROA}=\frac{\text { Laba Sebelum Pajak }}{\text { Total Aset }} \times 100 \% \ldots
$$

\section{Populasi dan Sampel}

Populasi dalam penelitian ini adalah seluruh perusahaan dalam seluruh perbankan yang berkategori Bank Go Public di Indonesia 2014 - 2018. Populasi dalam penelitian ini adalah sebanyak 43 perbankan yang tercatat sampai dengan tahun 2018 . Pemilihan sampel dilakukan dengan menggunakan metode purposive sampling (pertimbangan tertentu) yaitu dengan pertimbangan yaitu pada tahun $2014-2018$ tersedia data dengan lengkap. Pengumpulan data menggunakan panel, sehingga selama 5 tahun periode penelitian jumlah observasi sebanyak 41 perusahaan dan 205 observasi. Bank Go Public

\section{Jenis dan Metode Pengumpulan Data}

Data yang digunakan dalam penelitian ini adalah data kuantitatif berupa laporan keuangan publikasi tahunan yang diterbitkan oleh Bank Indonesia yang diperoleh dari WEB OJK dari periode tahun 2014 sampai tahun 2018. Sumber data yang digunakan ini diperoleh melalui penelusuran dari media internet dari www. ojk.go.id.Metode pengumpulan data yang digunakan yaitu melalui studi pustaka dari direktori perusahaan go publik dan situs resmi tiap perusahaan.idx.go.id. serta situs - situr resmi lainnya yang dijadikan sampel.

\section{Alat Analisis Data}

\section{Uji Persamaan Regresi Ganda Tahap 1}

Analisis regresi linier berganda adalah pengaruh secara linier antara dua atau lebih variabel independen dengan satu variabel dependen, yaitu pengaruh dari loan to 
deposit ratio $(L D R)$, biaya operasional terhadap pendapatan operasional (BOPO) dan capital adequacy ratio (CAR), terhadap net interest margin (NIM). (Astohar, 2013).

Persamaan regresi pada penelitian ini terdapat dua model. yaitu sebagai berikut:

$Y_{1}=a+b_{1} X_{1}+b_{2} X_{2}+b_{3} X_{3}+b_{4} X_{4}+b_{5} X_{5}$

Dimana :

$\mathrm{Y}_{1}: \mathrm{NIM}$

$\mathrm{X}_{1}: \mathrm{LDR}$

$\mathrm{X}_{2}: \mathrm{BOPO}$

$\mathrm{X}_{3}: \mathrm{CAR}$

\section{Uji Persamaan Regresi Ganda tahap 1}

Analisis regresi linier berganda adalah pengaruh secara linier antara dua atau lebih variabel independen dengan satu variabel dependen, yaitu pengaruh dari capital adequacy ratio $(C A R)$, loan to deposit ratio $(L D R)$, dan biaya operasional terhadap pendapatan operasional (BOPO) serta net interest margin (NIM) terhadap Return on asset (ROA). Sebelum melakukan estimasi yang tidak biasa dengan analisis regresi, perlu dilakukan uji $\mathrm{t}$ dan uji Fit data yaitu pengujian antar variabel bebas supaya tidak terjadi multikolinieritas, heteroskedastisitas, normalitas, dan autokorelasi (Astohar, 2013). berikut:

Persamaan regresi pada penelitian ini terdapat dua model. yaitu sebagai

$Y_{2}=a+b_{1} X_{1}+b_{2} X_{2}+b_{3} X_{3}+b_{4} X_{4}+b_{5} X_{5}$

Dimana :

$\mathrm{Y}_{2}: \mathrm{ROA}$

$\mathrm{X}_{1}: \mathrm{CAR}$

$\mathrm{X}_{2}: \mathrm{LDR}$

$\mathrm{X}_{3}: \mathrm{BOPO}$

$\mathrm{X}_{4}: \mathrm{NIM}$

\section{Uji Persamaan Regresi Sederhana}

Analisis regresi linier sederhana adalah pengaruh secara linier antara variabel independen dengan variabel dependen, yaitu pengaruh dari net interest margin (NIM) terhadap Return on Asset (ROA). Sebelum melakukan estimasi yang tidak biasa dengan analisis regresi, perlu dilakukan uji $\mathrm{t}$ dan uji Fit data yaitu pengujian antar variabel bebas supaya tidak terjadi multikolinieritas, heteroskedastisitas, normalitas, dan autokorelasi (Astohar, 2013).

Persamaan regresi pada penelitian ini terdapat dua model. yaitu sebagai berikut:

$\mathrm{Y}_{2}=\mathrm{a}+\mathrm{b}_{5} \mathrm{Y}_{1}$

Dimana :

$\mathrm{Y}_{2}: \mathrm{ROA}$

$\mathrm{Y}_{1}: \mathrm{NIM}$

\section{Uji Koefisien Determinasi}

Koefisien determinan pada penelitian ini digunakan untuk melihat berapa persen dari variasi variabel terikat dijelaskan variabel bebas. Pada penelitian ini koefisien determinasi adalah mengetahui seberapa besar variasi profitabilitas Bank Go Public (ROA) dapat diterangkan oleh variasi dari capital adequacy ratio (CAR), loan to deposit ratio $(L D R)$, biaya operasional terhadap pendapatan operasional (BOPO) serta net interest margin (NIM). Nilai determinasi yang digunakan pada penelitian ini adalah nilai 
adjusted $R^{2}$. Digunakannya nilai tersebut karena nilai adjusted $R^{2}$ pada saat mengevaluasi model regresi dapat naik atau turun apabila satu variabel independen ditambahkan ke dalam model (Ghozali, 2013).

Sobel Test

Uji Sobel ini dilakukan dengan cara menguji kekuatan pengaruh tidak langsung variabel independen $(\mathrm{X})$ kepada variabel dependen $(\mathrm{Y})$ melalui variabel intervening $(\mathrm{M})$ dalam hal ini adalah menguji pengaruh tidak langsung variabel capital adequacy ratio, loan to deposit dan biaya operasional terhadap pendapatan opersional secara tidak langsung terhadap return on asset melalui net interest margin. Suatu variabel disebut variabel intervening jika variabel tersebut ikut mempengaruhi hubungan antara variabel prediktor (independen) dan variabel criterion (dependen) (Baron dan Kenny (1986) dalam Ghozali (2009). Pengujian hipotesis mediasi dapat dilakukan dengan prosedur yang dikembangkan oleh Sobel (1982) dan dikenal dengan Uji Sobel (Sobel Test).

Berdasarkan hasil perhitungan diperoleh hasil sebagai berikut :

Kriteria pengambilan keputusan :

Apabila t sobel $>\mathrm{t}$ tabel : variabel terbukti sebagai variabel intervening

Apabila t sobel < t tabel : variabel tidak terbukti sebagai variabel intervening

HASIL DAN PEMBAHASAN

\section{Analisis Deskriptif}

Pada variable profitabilitas Bank Go Public (ROA) yang rata-ratanya adalah sebesar 1,09 \%. Berdasarkan rata - rata, Bank Go Public masuk dalam kategori yang kurang sehat, hal ini ditandai dengan rata - rata return on asset Bank Go Public masih dibawah 1,5\% (Ketentuan Bank Indonesia > 1,5\%). Berdasarkan data yang diperoleh profitabilitas Bank Go Public (ROA) terendah pada periode penelitian yaitu sebesar 9,58 \% yaitu pada PT. Bank Pundi Indonesia Tbk pada tahun 2016. Rasio profitabilitas Bank Go Public (ROA) tertinggi adalah pada Bank Centra Asia, Tbk pada tahun 2018 yaitu sebesar $4,02 \%$.

Pada variabel loan to deposit ratio (LDR) ini menunjukkan bahwa berdasarkan rata - rata Bank Go Public masuk dalam kategori yang sehat, hal ini ditandai dengan rata - rata loan to deposit ratio (LDR) masih dikisaran 85,12 \% (Ketentuan Bank Indonesia $85 \%$ sampai dengan $110 \%)$. Loan to deposit ratio (LDR) yang paling rendah pada penelitian yaitu sebesar 41,99 \% adalah pada Bank Mitra Niaga, Tbk pada tahun 2018. Rasio loan to deposit ratio (LDR) yang tertinggi adalah pada Bank Woori Saudara Indonesia pada tahun 2018 yaitu sebesar 145,26\%.

Pada variabel rasio beban operasional dibanding dengan pendapatan operasional (BOPO) ini menunjukkan bahwa berdasarkan rata - rata Bank Go Public masuk dalam kategori yang sehat, hal ini ditandai dengan rata - rata BOPO masih dikisaran 89,86 \% (Ketentuan Bank Indonesia < $100 \%$ ). Berdasarkan deskriptif data yang didapatkan BOPO terendah pada selama periode penelitian adalah sebesar 58,20\% pada Bank Central Asia, Tbk pada tahun 2018. Rasio BOPO tertinggi adalah pada Bank Pundi Indonesia, Tbk pada tahun 2016 yaitu sebesar 195,7 \%.

Pada variabel capital adequacy ratio $(C A R)$ ini menunjukkan bahwa berdasarkan rata - rata Bank Go Public masuk dalam kategori yang sehat, hal ini ditandai dengan rata - rata capital adequacy ratio (CAR) masih dikisaran 20,44\% (Ketentuan Bank Indonesia > $8 \%$ ). Capital adequacy ratio $(C A R)$ terendah pada periode penelitian yaitu sebesar 10,04 \% yaitu pada Bank Pundi Indonesia, Tbk pada tahun 2018. Rasio capital adequacy ratio (CAR) tertinggi adalah pada Bank Ina Perdana, Tbk pada tahun 2017 yaitu sebesar 66,43 5. 
Pada variabel rasio net interest margin (NIM) ini menunjukkan bahwa berdasarkan rata - rata Bank Go Public masuk dalam kategori yang sehat, hal ini ditandai dengan rata - rata NIM masih dikisaran 5,01\% (Ketentuan Bank Indonesia > $1,5 \%$ ). Berdasarkan deskriptif data yang didapatkan net interest margin (NIM) terendah pada selama periode penelitian adalah sebesar 1,53\% pada Bank Victoria International pada tahun 2016. Rasio net interest margin (NIM) tertinggi adalah pada Bank Tabungan Pensiunan Nasional, Tbk yaitu sebesar 11,60\%.

\section{Uji Normalitas dan Penyimpangan Asumsi Klasik}

Data yang digunakan untuk penelitian terdistribusi secara normal, yang ditandai dengan print out grafik erlihat titik-titiknya nampak menyebar menjauh atau tidak berada disekitar pada garis diagonal, serta penyebaran titik - titiknya tidak mengikuti garis diagonal. Selain pada grafik histogram yang menunjukkan data tersebar tidak mendekati garis normalitas. Berdasarkan uji Kolmogorov Smirnov sebesar 0,261 yang mana nilai signifikansi tersebut lebih besar dari nilai signifikansi yang telah ditentukan yaitu 0,05. Berdasarkan data tersebut dapat dijelaskan bahwa model regresi telah terdistribusi secara normal.

Hasil pengujian penyimpangan asumsi klasik menunjukkan bahwa model tidak terjadi penyimpangan multikolinearitas yang ditandai dengan nilai VIF dibawah 10 yaitu : 1,$108 ; 1,288 ; 1,090$ dan 1,330 serta nilai tolerance diatas 0,1 yaitu 0,$902 ; 0,777$ ; 0,917dan 0,752. Grafik scatterplot tidak membentuk pola yang khusus atau jelas, hal ini menunjukkan data tidak terjadi penyimpangan heteroskedastisitas. Nilai durbin Watson sebesar 1,655 yang mana nilai tersebut berada pada tanpa kesimpulan dan tidak terjadi autokorelasi.

Hasil perhitungan anova didapatkan nilai $F$ hitungnya sebesar 2901,684 nilai probabilitas adalah 0,000 . Hasil ini dikatakan bahwa permodelan yaitu variabel bebas yang berupa LDR, BOPO dan CAR secara bersama - sama (simultan) mempunyai pengaruh signifikan terhadap profitabilitas pada Bank Go Public, atau model yang dibangun memenuhi kriteria fit.

\section{Analisis Regresi Linier Berganda Tahap 1}

Berdasarkan hasil print out spss dapat disajikan persamaan sebagai berikut

$\mathrm{NIM}=5,734+0,024$ LDR - 0,036 BOPO + 0,024 CAR

Nilai konstanta pada penelitian ini diperoleh nilai 5,734 yang dapat diartikan bahwa tanpa adanya perubahan dari variabel bebas atau variabel LDR, BOPO dan CAR maka pendapatan bunga (net interest margin) pada Bank Go Public mengalami peningkatan

Loan to deposit ratio (LDR) Bank Go Public di Indonesia mempunyai pengaruh positif terhadap pendapatan bunga (net interest margin) dengan koefisien regresi sebesar 0,024. Hal ini dapat diartikan bahwa setiap peningkatan Loan to deposit ratio (LDR) maka pendapatan bunga (net interest margin) pada Bank Go Public di Indonesia mengalami peningkatan pula. Hipotesis diterima, karena ditunjukkan dengan nilai probabilitas (sig) sebesar 0,004 yang mana nilai tersebut dibawah 0,05.

Biaya operasional dan pendapatan opoerasional (BOPO) Bank Go Public di Indonesia mempunyai pengaruh negatif terhadap profitabilitas bank dengan koefisien regresi sebesar - 0,036. Hal ini dapat diartikan bahwa setiap peningkatan BOPO maka profitabilitas pada Bank Go Public di Indonesia mengalami penurunan atau sebaliknya setiap penurunan BOPO akan meningkatkan profitabilitas. Hipotesis diterima, karena dibuktikan dengan nilai probabilitas (sig) sebesar 0,000 yang mana nilai tersebut dibawah 0,05 . 
Capital adequacy ratio (CAR) Bank Go Public di Indonesia mempunyai dampak positif terhadap pendapatan bunga (net interest margin) bank dengan koefisien regresinya sebesar 0,024. Ini dapat dijelaskan setiap adanya peningkatan Capital adequacy ratio $(C A R)$ atau semakin tinggi CAR maka pendapatan bunga (net interest margin) Perkreditan Rakyat di Indonesia akan mengalami peningkatan. Hipotesis ditolak pada taraf signifikan $5 \%$, ini ditunjukkan melalui nilai probabilitas (sig) sebesar 0,126 di mana nilai probabilitas tersebut diatas 0,05 .

\section{Analisis Regresi Linier Berganda Tahap 2}

Berdasarkan hasil print out spss dapat disajikan persamaan sebagai berikut $\mathrm{ROA}=10,558$ - 0,003 LDR - 0,101 BOPO - 0,007 CAR

Nilai konstanta pada penelitian ini diperoleh nilai 10,558 yang dapat diartikan bahwa tanpa adanya perubahan dari variabel bebas atau variabel LDR, BOPO dan CAR maka profitabilitas pada Bank Go Public mengalami peningkatan

Loan to deposit ratio (LDR) Bank Go Public di Indonesia mempunyai pengaruh negatif terhadap profitabilitas bank dengan koefisien regresi sebesar - 0,003. Hal ini dapat diartikan bahwa setiap peningkatan Loan to deposit ratio (LDR) maka profitabilitas pada Bank Go Public di Indonesia mengalami penurunan. Hipotesis ditolak, karena ditunjukkan dengan nilai probabilitas (sig) sebesar 0,076 yang mana nilai tersebut diatas 0,05 .

Biaya operasional dan pendapatan opoerasional (BOPO) Bank Go Public di Indonesia mempunyai pengaruh negatif terhadap profitabilitas bank dengan koefisien regresi sebesar - 0,101. Hal ini dapat diartikan bahwa setiap peningkatan BOPO maka profitabilitas pada Bank Go Public di Indonesia mengalami penurunan atau sebaliknya setiap penurunan BOPO akan meningkatkan profitabilitas. Hipotesis diterima, karena dibuktikan dengan nilai probabilitas (sig) sebesar 0,000 yang mana nilai tersebut dibawah 0,05 .

Capital adequacy ratio (CAR) Bank Go Public di Indonesia mempunyai dampak negatif terhadap profitabilitas bank dengan koefisien regresinya sebesar - 0,007. Ini dapat dijelaskan setiap adanya peningkatan Capital adequacy ratio (CAR) atau semakin tinggi CAR maka profitabilitas pada Bank Go Public di Indonesia akan mengalami penurunan. Hipotesis diterima pada taraf signifikan $5 \%$, ini ditunjukkan melalui nilai probabilitas (sig) sebesar 0,011 di mana nilai probabilitas tersebut dibawah 0,05.

\section{Analisis Regresi Linier Tahap 3}

Berdasarkan hasil print out spss dapat disajikan persamaan sebagai berikut ROA $=-1,726+0,563$ NIM

Nilai konstanta pada penelitian ini diperoleh nilai - 1,726 yang dapat diartikan bahwa tanpa adanya perubahan dari variabel bebas atau variabel NIM maka profitabilitas (return on asset) pada Bank Go Public mengalami penurunan.

Net interest margin (NIM) Bank Go Public di Indonesia mempunyai pengaruh positif terhadap profitabilitas bank dengan koefisien regresi sebesar 0,563. Hal ini dapat diartikan bahwa setiap peningkatan NIM maka profitabilitas pada Bank Go Public di Indonesia mengalami peningkatan atau sebaliknya setiap penurunan NIM juga akan menurunkan profitabilitas. Hipotesis diterima pada taraf $5 \%$, karena dibuktikan dengan nilai probabilitas (sig) sebesar 0,000 yang mana nilai tersebut dibawah 0,05.

\section{Koefisien Determinasi}

Berdasarkan hasil perhitungan diperoleh nilai koefisien determinasi (Adjusted $R$ Square) sebesar sebesar 0,235. Hal ini berarti besar variasi variabel pendapatan bunga (net interest margin) pada Bank Go Public di Indonesia yang dapat diterangkan oleh 
variasi variabel $\mathrm{LDR}$, BOPO dan CAR adalah sebesar 23,5\%, sedangkan sisanya sebesar 76,5\% dipengaruhi oleh variabel lain di luar model penelitian.

Sobel Test

\section{Peran Net Interest Margin dalam Mediasi Pengaruh Loan to Deposit Ratio terhadap} Return on Investment1

Berdasarkan hasil perhitungan diperoleh nilai sobel test sebesar 7,192 dan nilai t tabel sebesar 1,96. Perbandingan tersebut menunjukkan sobel test $>\mathrm{t}$ tabel $(7,192>$ 1,96) sehingga dapat dijelaskan bahwa ada peran net interest margin dalam memediasi pengaruh loan to deposit ratio terhadap return on investment. Hasil tersebut menunjukkan bahwa net interest margin terbukti signifikan dalam memediasi pengaruh loan to deposit ratio terhadap return on asset pada Bank Go Public di Indonesia.

Peran Net Interest Margin dalam Mediasi Pengaruh Biaya Operasional pada Pendapatan Operasional terhadap Return on Investment

Berdasarkan hasil perhitungan diperoleh nilai sobel test sebesar - 4,662 dan nilai t tabel sebesar 1,96. Perbandingan tersebut menunjukkan - sobel test $<-\mathrm{t}$ tabel $(-4,662<-$ 1,96) sehingga dapat dijelaskan bahwa ada peran net interest margin dalam memediasi pengaruh biaya operasional pada pendapatan operasional terhadap return on investment. Hasil tersebut menunjukkan bahwa net interest margin terbukti signifikan dalam memediasi pengaruh biaya operasional pada pendapatan operasional terhadap return on asset pada Bank Go Public di Indonesia.

Peran net Interest Margin dalam Mediasi Pengaruh Capital Adequacy Ratio terhadap Return on Investment

Berdasarkan hasil perhitungan diperoleh nilai sobel test sebesar 1,564 dan nilai $\mathrm{t}$ tabel sebesar 1,96. Perbandingan tersebut menunjukkan sobel test $<\mathrm{t}$ tabel $(1,564<$ 1,96) sehingga dapat dijelaskan bahwa tidak ada peran net interest margin dalam memediasi pengaruh capital adequacy ratio terhadap return on investment. Hasil tersebut menunjukkan bahwa net interest margin tidak terbukti signifikan dalam memediasi pengaruh capital adequacy ratio terhadap return on asset pada Bank Go Public di Indonesia.

\section{PENUTUP}

\section{Implikasi Manajerial}

1. Pos - pos atau kegiatan yang dirasa membutuhkan dana atau anggaran yang tinggi perlu mendapatkan prioritas agar efisiensi dam penghematan anggaran dapat diwujudkan

2. Kebutuhan pembiayaan bener - benar diperhatikan atau disesuaikan dengan dana pihak ketiga dari simpanan dan modal inti. Langkah ini dapat dilakukan dengan mengupdate pembiayaan yang telah dilakukan secara lebih cepat atau pendek (per minggu).

3. Modal yang terlalu tinggi atau berlebihan dibanding dengan aktivanya, apabila rasio permodalan ini terlalu rendah akan mengganggu stabilitas bank. Bank sebaiknya selalu memonitor modal yang dibutuhkan agar rasio ini pada posisi yang aman dan efisien.

\section{Kelemahan Penelitian}

Penelitian ini masih terbatas pada sektor bank Bank Go Public di Indonesia. Sehingga hasil penelitian ini tidak dapat digeneralisasi pada kasus lain diluar obyek penelitian seperti pada bank umum. Pada sektor bank lainnya sangat berbeda dengan bank Bank Go Public. 


\section{Agenda Mendatang}

1. Memperluas obyek perbankan yang terdapat unit usaha yang lebih luas (semua bank di Indonesia).

2. Menambah variabel yang mempengaruhi profitabilitas bank Bank umum nasional.

3. Mengembangkan permodelan structural dengan variabel intervening ataupun variabel moderating sekaligus.

\section{ACKNOWLEDGMENTS}

Penelitian ini didukung dan dibiaya sepenuhnya oleh Penelitian Dosen Pemula

Kementrian Riset, Teknologi dan Pendidikan Tinggi (RISTEKDIKTI) Republik Indonesia 2019

\section{DAFTAR PUSTAKA}

Achmad, S. 2003. Ekonomi Perbankan. Jakarta: STIE Gunadarma.

Ali, Muhammad dan Laksono, Roosaleh., 2017., Pengaruh Net Interest Margin (NIM), Biaya Operasional Terhadap Pendapatan Operasional BOPO), Loan to Deposit Ratio (LDR) dan Non Performing Loan (NPL)Terhadap (ROA)., Jurnal Riset Akuntansi Dan Keuangan, Vol 5 Nomor 2, Bandung.

Alifah, Yonira Bagiani., 2014., Pengaruh CAR, NPL, BOPO, dan LDR terhadap Profitabilitas Bank (ROA) pada Perusahaan Perbankan tang Terdaftar di Bursa Efek Indonesia Periode 2009-2012., Skripsi., Program Studi Manajemen, FE., Universitas Negeri Yogyakarta.

Ariyanti, Indah., Dhiana, Patricia dan Pranaditya, Ari., 2017., Pengaruh CAR, NPF, NIM, BOPO, dan DPK terhadap Profitabilitas dengan FDR Sebagai Variabel Intervening (Studi Kasus Perbankan Umum Syariah Tahun 2011-2014)., Jurnal Akuntansi., Universitas Pandanaran.

Aprillya, Agnes., Effendi, Rizal, Nyimas Artina., 2017., Analisis Pengaruh Non Performing Loan (NPL), Loan to Deposit Ratio (LDR) dan Capital Adequacy Ratio (CAR) Terhadap Return On Asset (ROA) pada Bank BUMN yang Terdaftar di BEI Periode Tahun 2012 - 2016., Jurusan Manajemen., STIE Multi Data Palembang

Alshatti, Ali Sulieman., 2015., The Effect of the Liquidity Management on Profitability in the Jordanian Commercial Banks., International Journal of Business and Management; Vol. 10, No. 1; 2015

Almilia, Luciana Spica dan Winny Herdiningtyas, 2005. Analisis Rasio CAMEL terhadap Prediksi Kondisi Bermasalah Pada Lembaga Perbankan Periode 20002002. Jurnal Akuntansi dan Keuangan, Vol.7, No.2.

Astohar., 2013., Statistika Bisnis Kasus dan Solusi., Penerbit Duta Nusindo., Semarang. Astohar., 2016., Pengaruh Capital Adequacy Ratio (Car) Dan Financing To Deposit Ratio Terhadap Profitabilitas Perbankan Bank Go Public Di Indonesia Dengan Inflasi Sebagai Variabel Pemoderasi., Among Makarti Vol.9 No.18, Desember 2016

Astohar, 2018., Analisis Faktor - Faktor Yang Berpengaruh terhadap Profitabilitas Perbankan yang Go Public di Bursa Efek Indonesia pada tahun 2012 - 2016., Jurnak Dinamika Ekonomi \& Bisnis (JDEB)., Vol 15 No 1., Maret 2019

Bernardin, Deden Edwar Yokeu., 2016., Pengaruh CAR dan LDR terhadap Return on Asset., Edodemica., Vol. IV., No.2 September 2016 
Chandra, Ronny 2013, Analisis Pengaruh Capital Adequacy Ratio, Operational Efficiency, Non Performing Loan, Dan Loan To Deposit Ratio Terhadap Return On Asset Pada Bank BUMN Di Indonesia, Jurnal, Universyitas Syiah Kuala Banda Aceh, Diakses 24 Juli 2017, dari www.jurnal.unsyiah.ac.id

Defri., 2012., Pengaruh Capital Adequacy Ratio (CAR), Likuiditas Dan Efisiensi Operasional Terhadap Profitabilitas Perusahaan Perbankan Yang Terdaftar Di BEI., Jurnal Manajemen, Volume 01, Nomor 01, September 2012

Dendawijaya, Lukman. 2009. Manajemen Perbankan. Jakarta: Ghalia Indonesia.

Dewi, Luh Eprima, Nyoman Trisna Herawati, Luh Gede Erni Sulindawati. 2015. "Analisis Pengaruh NIM, BOPO, LDR, dan NPL Terhadap Profitabilitas (Studi Kasus Pada Bank Umum Swasta Nasional Yang Terdaftar Pada Bursa Efek Indonesia Periode 2009-2013)". E-Journal S1 Ak. Universitas Pendidikan Ganesha, Vol.3 N0.1 Hal. 10.

Fahmi, Irfam 2015, Manajemen Perbankan Konvensional \& Syariah, Penerbit Mitra Wacana Media, Jakarta.

Fajari, S dan Sunarto., (2017). Pengaruh CAR, LDR, NPL, BOPO terhadap Profitabilitas Bank (Studi Kasus Perusahaan Perbankan yang tercatat di Bursa Efek Indonesia Periode Tahun 2011 Sampai 2015 ). Prosiding Seminar Nasional Multi Disiplin Ilmu \& Call For Papers Unisbank Ke-3

Fauziah, Ravika, 2011., "Analisis Pengaruh Inflasi Terhadap Tingkat Profitabilitas Bank Muamalat Indonesia dan Bank Central Asia (BCA) Tahun 2007-2011", Universitas Negeri Surabaya, Surabaya, 2011

Ghozali, Imam, 2007, Manajemen Risiko Perbankan Pendekatan VaR, Badan Penerbit Universitas Diponegoro, Semarang.

Greuning, H.v. dan S.B. Bratanovic. 2011. Analisis Risiko Perbankan. Ed. 3. Jakarta: Salemba Empat

Hery., 2015., Analisis Laporan Keuangan Pendekatan Rasio Keuangan., Yogyakarta : Center for Academic Publishing Services

Husnan, Suad, 2012, Manajemen Keuangan - Teori dan Penerapan, Buku 2, BPFE Yogyakarta.

Kasmir 2012, Manajemen Perbankan, Edisi Revisi, Rajawali Pers, Jakarta.

Khoirunnisa, Hani Maulida, Rodhiyah, Saryadi., 2016., Pengaruh Capital Adequacy Ratio (CAR), Loan To Deposit Ratio (LDR) dan BOPO terhadap Profitabilitas (ROA dan ROE) Bank Persero Indonesia yang Dipublikasikan Bank Indonesia Periode 2010 - 2015., Jurnal Administrasi Bisnis., Semarang.

Kuncoro, Mudrajad dan Suhardjono. 2002. Manajemen Perbankan Teori dan Aplikasi. Yogyakarta; BPFE UGM.

Latifah, Nurul Maulidya, Rodhiyah, Saryadi. 2012, Pengaruh Capital Adequacy Ratio (CAR), Non Performing Loan (NPL) dan Loan to Deposit Ratio (LDR) terhadap (ROA) (Studi kasus pada Bank Umum Swasta Nasional Devisa Go Public di Bursa Efek Indonesia Periode 2009-2010)., Jurnal Ilmu Administrasi Bisnis., Semarang.

Lesmana, Yuanita. 2008 "Konsistensi Antara Discretionary Accrual dengan rasi Keuangan Camel dalam Mengukur Tingkat Kesehatan Bank”.Usahawan , No. 05 tahun XXXVII. 2008 
Martindas, Anggria Maya., Pangemanan, Sifrid S. dan David P.E. Saerang., 2013., Pengaruh Capital Adequacy Ratio (CAR), BOPO dan Non Performing Loan (NPL) terhadap Kinerja Keuangan Perbankan di Indonesia., Jurnal Unsrat.

Milion, Lie Jimmy., Utary, Anis Rachma., Irwansyah., 2017., Pengaruh Non Performing Loan dan Capital Adequacy Ratio serta Biaya Operasional terhadap Net Interest Margin dan Return On Asset., prosiding Seminar Nasional Manajemen dan Ekonomi Bisnis., Volume 1., Mei 2017.

Musyarofatun, Lia Dwi 2013, Analisis Faktor-Faktor Yang Mempengaruhi Rentabilitas Bank Perkreditan Rakyat Di Kabupaten Magelang, Skripsi S1, Universitas Negeri Semarang, Diakses 10 Agustus 2017, dari www.lib.unnes.ac.id

Pandia, Frianto., 2012., Manajemen Dana dan Kesehatan Bank. Rineka Cipta., Jakarta

Peling, Ida Ayu Adiatmayani dan Sedana, Ida Bagus Panji., 2018., Pengaruh LDR, NPL, dan BOPO terhadap Profitabilitas pada PT. BPD Bali Periode Tahun 2009-2016., EJurnal Manajemen Unud, Vol. 7, No. 6, 2., Bali

Putrianingsih, D,I., dan $\square$ Yulianto, A., (2016). Pengaruh Non Performing Loan (NPL) dan Capital Adequacy Ratio (CAR) terhadap Profitabilitas., Management Analysis Journal 5 (2) (2016)

Rahmani, Nur Ahmadi Bi., 2017., Analisis Pengaruh Capital Adequacy Ratio (CAR) dan Financing to Deposit Ratio (FDR) terhadap (ROA) dan Return On Equity (ROE) Pada Perusahaan Bank Bank Go Public di Indonesia., Jurnal Human Falah., Vol 4 Nomor 4. Yogyakarta.

Sartono, Agus. 2010. Manajemen Keuangan Teori dan Aplikasi. Edisi Empat. Yogyakarta: BPFE-Yogyakarta

Simanjuntak, Jontro., 2016., Pengaruh Capital Adequacy Ratio (CAR), Loan to Deposit Ratio (LDR) dan Non Performing Loan (NPL) Terhadap s (ROA) Pada Sektor Perbankan di Bursa Efek Indonesia., Jurnal Bisnis dan Manajemen Vol 2 Nomor 2.

Simorangkir, O.P. (2004). Pengantar Lembaga Keuangan Bank dan non Bank. Jakarta: Ghalia Indonesia.

Sintiya Siti., 2018., Analisis Pengaruh BOPO, FDR dan CAR terhadap Profitabilitas Bank Umum Syariah Periode 2012-2016 (Studi Kasus pada Bank Umum Syariah di Indonesia Periode 2012-2016)., Skripsi., Prodi Perbankan Syariah., FEBI., IAIN Salatiga.

Sitepu, Jurnal., Dzulkirom, Moch., Azizah, Devi Farah., 2016., Pengaruh Capital Adequacy Ratio, Biaya Operasional Per Pendapatan Operasional, Non Performing Loan, Net Interest Margin Dan Loan To Deposit Ratio Terhadap Return On Asset (Studi pada Perusahaan Sektor Perbankan yang terdaftar di Bursa Efek Indonesia Periode Tahun 2012-2015)., Jurnal Administrasi Bisnis (JAB)|Vol. 40 No. 2 November 2016

Sudarmawanti, Erna dan Pramono, Joko, 2017., Pengaruh CAR, NPL, BOPO, NIM dan LDR terhadap ROA (Studi kasus pada Bank Go Public di Salatiga yang terdaftar di Otoritas Jasa Keuangan Tahun 2011-2015)., AmongMakarti., Vol 10 No 19.

Sudarmanta, I Ketut 2016, Determinasi Profitabilitas Sektor Perbankan Di Bursa Efek Indonesia, Pascasarjana Universitas Warmadewa, Denpasar, Diakses 22 Agustus 2017, dari www.ejournal.warmadewa.ac.id 